\title{
PHOTOPHYSICAL RELAXATION MECHANISM OF EXCITED PHTALIMIDE COMPOUNDS
}

\author{
I. Čiplys ${ }^{a}$, R. Orita ${ }^{b}$, S. Ando ${ }^{b}$, and V. Gulbinas ${ }^{a}$ \\ ${ }^{a}$ Center for Physical Sciences and Technology, Sauletekio 3, 10257 Vilnius, Lithuania \\ ${ }^{\mathrm{b}}$ Department of Chemical Science and Engineering, Tokyo Institute of Technology, Ookayama 2-12-1-E4-5, Meguro-ku, \\ Tokyo 152-8552, Japan \\ Email: vidmantas.gulbinas@ftmc.lt
}

Received 11 December 2018; accepted 2 January 2019

\begin{abstract}
Fluorescent polymers are one of the most desired materials for making novel flexible electronic components or spectral converters. Favourable properties of polyimides (PIs) make them a potentially attractive class of polymers but, unfortunately, they generally show a very weak fluorescence. As a result, there has been a large amount of work directed towards finding the reasons behind the lack of fluorescence of PIs and making their new fluorescent variants. Amine-substituted phtalimides are heavily used as model compounds for fluorescent PIs. In this work we have examined the photophysical relaxation mechanism of such two phtalimides (3Pi and 3Pyr) that were previously discovered to have low quantum yields of fluorescence. Our aim was to find the reason behind this lack of fluorescence and to suggest ways to make these properties more attractive. We have investigated the photophysics of phtalimides by time resolved fluorescence and ultrafast transient absorption techniques in solvent mixtures of different viscosities. Our results demonstrate that intramolecular rotation is a crucial process that opens up an alternative relaxation pathway to fluorescence in phtalimides, which has to be suppressed for designing more fluorescent materials.
\end{abstract}

Keywords: fluorescent polymers, ultrafast spectroscopy, photophysics

PACS: $33.50 . \mathrm{Dq}, 82.53 . \mathrm{Eb}$

\section{Introduction}

Fluorescent polymers are materials of great interest that can be applied for making organic light-emitting diodes [1], flexible electronic components [2] or polymer films that could convert sunlight into the light of desired wavelength [3]. The main requirement for a fluorescent polymer is a long conjugated $\pi$ structure, which is met by a number of different polymers, such as polythiophenes [4] or polyfluorenes [5]. Unfortunately, the majority of such polymers are not stable enough thermally and not durable enough, which impedes the fabrication of devices made out of such polymers.

A class of polymers that meet the criteria of durability and thermal stability are aromatic polyimides (PIs). The reason for these favourable properties is very rigid structures and strong intermolecular interactions between the polymer chains [6]. As a result, these polymers are being widely used in aerospace and electronics industries [7]. However, aromatic PIs generally exhibit coloration from yellow to brown, and their fluorescence is quite weak [8], which is the main obstacle preventing PIs from becoming the main class of fluorescent polymers.

In order to improve the fluorescence properties of PIs, first, the photophysical processes undergoing upon excitation need to be understood, and then a new molecular structure for a polymer needs to be designed that leads to strong fluorescent properties. Unfortunately, studying PIs is challenging because these are insoluble in polar organic solvents due to their strong interchain 
interactions. As a result, small model compounds resembling monomers of PIs are used for predicting properties of PIs themselves.

Previously, it has been discovered that the introduction of a strong electron-donating amino group into phtalimide, a model compound for PI, significantly enhanced its quantum yield of fluorescence [9, 10]. Therefore, a number of phtalimide compounds were synthesized containing tertiary amino groups at the 3- or 4-position [11]. It was discovered that while compounds with alicyclic amino groups at the 4-position had fluorescence quantum yields that exceeded $50 \%$ in the majority of the solvents, the compounds with exactly the same amino groups at the 3-position had $10 \%$ quantum yield of fluorescence at most. The explanation for such observation was that poorly fluorescent phtalimide derivatives formed a 'dark' twisted intramolecular charge transfer (TICT) state instead of fluorescing [11]. It was hypothesized that molecules relax from the TICT state back to the ground state non-radiatively and, as a result, an alternative relaxation channel to fluorescence is formed.

We have decided to test this hypothesis and investigate these phtalimide derivatives that presumably form the TICT states - 3Pi and $3 \mathrm{Pyr}$ (Fig. 1 $(a, b))$. We have used two experimental techniques - time-resolved fluorescence spectroscopy and femtosecond transient absorption. Both experiments were performed on the molecules that were in the environment of progressively increasing viscosity, since this should inhibit the formation of TICT states [12-14]. We have first determined the time that a molecule spends in the fluorescent state at different viscosities from time-resolved fluorescence experiments. Then we have proceeded to look for traces of any transient states formed upon exciting $3 \mathrm{Pi}$ and $3 \mathrm{Pyr}$ from transient absorption experiments with the aim to
$3 \mathrm{Pi}$

(a)<smiles>O=C1c2cccc(N3CCCCC3)c2C(=O)N1C1CCCCC1</smiles>

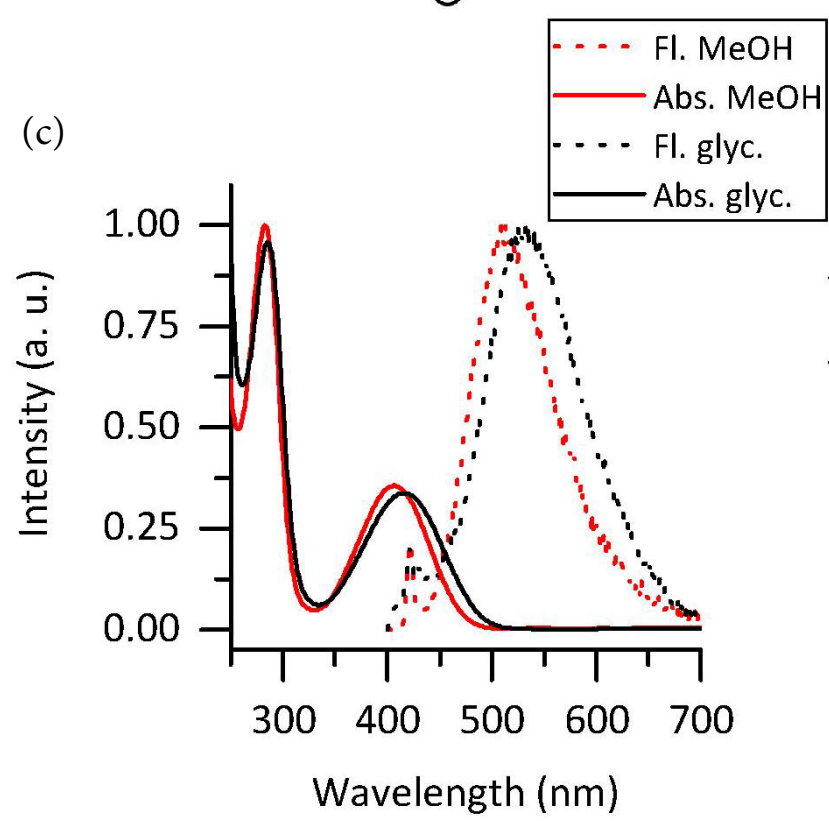

(b)

$3 \mathrm{Pyr}$<smiles>O=C1c2cccc(N3CCCC3)c2C(=O)N1C1CCCCC1</smiles>

(d)

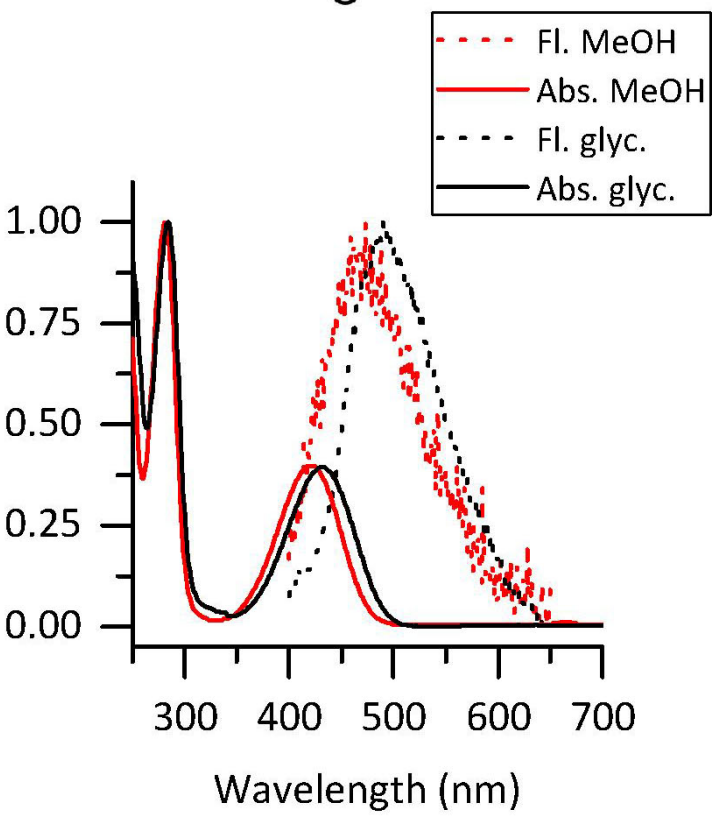

Fig. 1. The molecular structures of $3 \mathrm{Pi}(\mathrm{a})$ and $3 \mathrm{Pyr}(\mathrm{b})$ together with their absorption and fluorescence spectra in methanol and glycerol. The spectra of 3Pi are shown in (c), while the spectra of 3Pyr are shown in (d). 
reveal the full picture of the relaxation pathways of $3 \mathrm{Pi}$ and $3 \mathrm{Pyr}$ and the real reasons behind their weak fluorescent properties.

\section{Methods}

\subsection{Preparation of samples}

Concentrated stock solutions of $3 \mathrm{Pi}$ and $3 \mathrm{Pyr}$ (synthesis of dyes is presented elsewhere [11]) were prepared in methanol (Sigma-Aldrich, purity $>99.9 \%$ ) with an optical density of 50 . Further dilutions of the stock solutions were done in mixtures of glycerol (Sigma-Aldrich, purity >99.5\%) containing different fractions of methanol from 0 to $100 \%$. Fluorescence experiments were performed using diluted samples (optical density of 0.1 ) in $10 \mathrm{~mm}$ quartz cuvettes, whereas $2 \mathrm{~mm}$ cuvettes containing solutions with an optical density of 0.5 were used for transient absorption experiments.

\subsection{Absorption and time-resolved fluorescence spectroscopy}

Absorption experiments were performed using a V-670 spectrophotometer (JASCO Corp., Tokyo, Japan). Time-resolved fluorescence spectra were obtained using an Edinburgh-F900 (Edinburgh Instruments, Livingston, UK) fluorimeter with a time domain of 50 ns (4096 bins). An EPL-375 (Edinburgh Instruments) diode laser $(375 \mathrm{~nm}$, 100 ps pulse duration, $2 \mathrm{MHz}$ frequency) was used for sample excitation.

\subsection{Transient absorption spectroscopy}

The hardware setup for the transient absorption experiment contains a Pharos 10-600-PP laser (Light Conversion Ltd., Vilnius, Lithuania, $1028 \mathrm{~nm}, 50 \mathrm{kHz}$ frequency reduced to $4.54 \mathrm{kHz}$ ). The laser beam was separated into a pump and a probe beams. Before reaching the sample, the pump beam was sent through an Orpheus PO15F2L collinear optical parametric amplifier (Light Conversion Ltd.) to generate the desired light for excitation (390 nm). A chopper spinning at $757 \mathrm{~Hz}$ frequency was used to interrupt the continuous pumping of the sample. The probe beam was used for a broadband continuum generation covering the $380-700 \mathrm{~nm}$ spectral range. This was achieved using 2 crystals. The first crystal - BBO (1 $\mathrm{mm})$ - was used to generate the second harmonic $(515 \mathrm{~nm})$ of the probe beam, whereas the second crystal - Ti:sapphire - was used to generate continuum from the first (the red part of continuum) and the second harmonic (the blue part of continuum) of the incoming light. Delaying of the probe beam was ensured using a $40 \mathrm{~cm}$ (2000 ps) delay line (Aerosoft). For signal registration, the combination of an Andor-Shamrock SR500i-B1-R spectrometer (Andor Technology Ltd., Belfast, Ireland, 150 lines/mm diffraction grating) and an Andor-Newton (Andor Technology) DU970 CCD camera $(1600 \times 200$ pixels $)$ was used. All the hardware was controlled and synchronized using self-written algorithms in LabView 16.0 (National Instruments, Austin, US).

\subsection{Data analysis}

The data of time-resolved fluorescence experiments were processed and analysed using the F900 software (Edinburgh Instruments). The results of transient absorption experiments were analysed and processed using the Glotaran 1.5.1 software. [15] Further processing and data visualization were performed using OriginPro 8.5 (OriginLab Corp.).

\section{Results and discussion}

Previously, it has been postulated that upon excitation with light intramolecular charge transfer occurs in the phtalimide compounds $3 \mathrm{Pi}$ and $3 \mathrm{Pyr}$ leading to intramolecular rotation [1]]. As a result of such process, the molecules leave the initial fluorescent state and enter the TICT state. To test this hypothesis, we have measured time-resolved fluorescence decays of 3Pi and 3Pyr in the solvent mixtures with progressively increasing viscosity, which should suppress the intramolecular rotation and prolong the time molecules stay in the initial fluorescent state. Viscosity was varied by dissolving the fluorophores in methanol-glycerol mixtures by changing the proportion of glycerol. The absorption and fluorescence spectra of $3 \mathrm{Pi}$ and $3 \mathrm{Pyr}$ in methanol and glycerol are shown in Fig. 1 $1(c, d)$, respectively.

The time-resolved fluorescence decays recorded at $520 \mathrm{~nm}$ using a $375 \mathrm{~nm}$ excitation source are 
shown in Fig. 2( $(a, b)$ for $3 \mathrm{Pi}$ and 3 Pyr, respectively. The decays were clearly not mono-exponential, consisting of a short and a long decay component. In order to extract lifetimes of the components, multi-exponential fitting was performed; the results are shown in Fig. 2(c-f). While the biexponential fitting was sufficient for $3 \mathrm{Pyr}$, the triple exponential fit was required to be done on the data of 3Pi. However, a single component had a dominant amplitude, which was close to $100 \%$ at all viscosities for both compounds (Fig. 2(e, f). Only the dominant lifetime component of $3 \mathrm{Pi}$
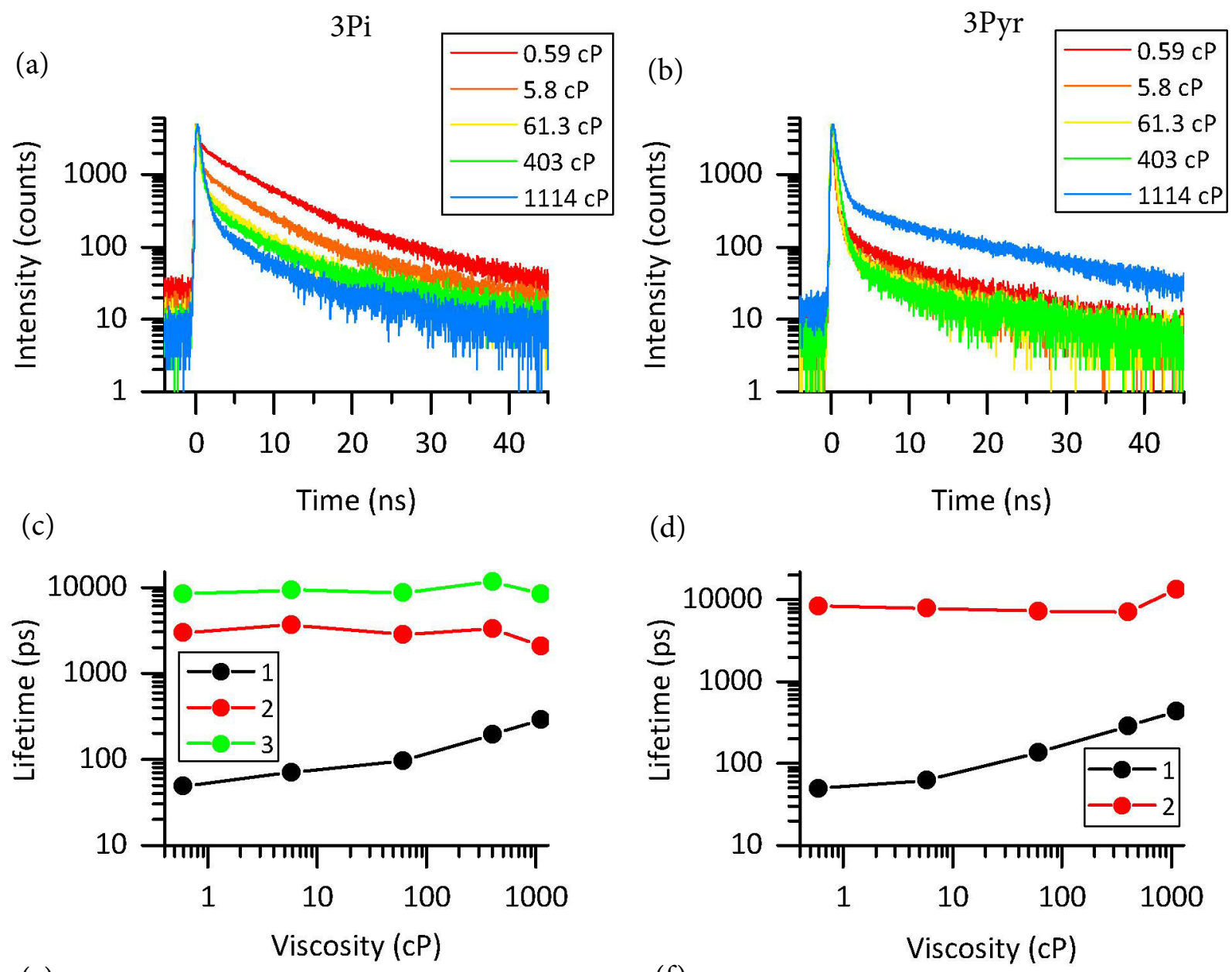

(e)
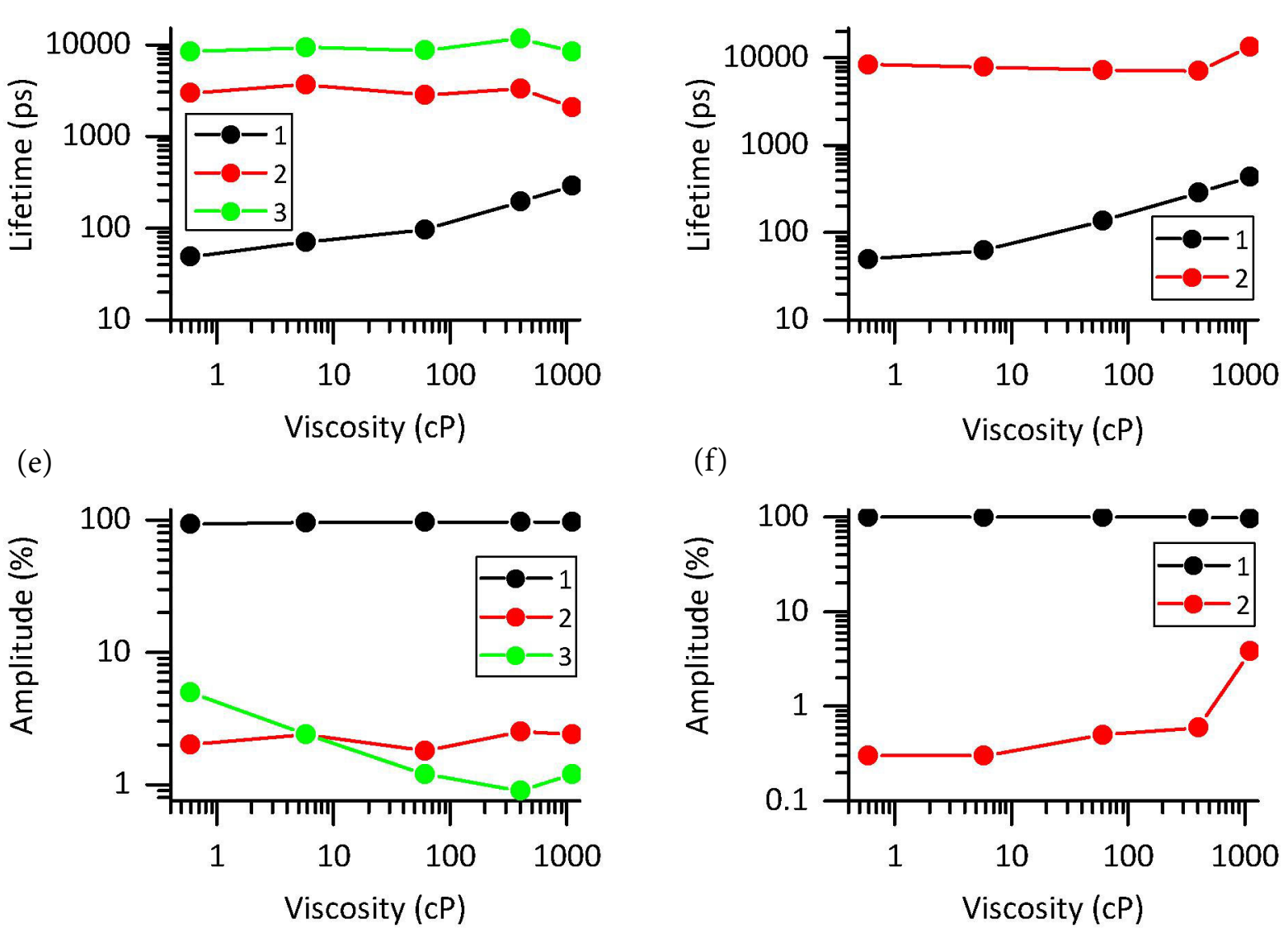

(f)

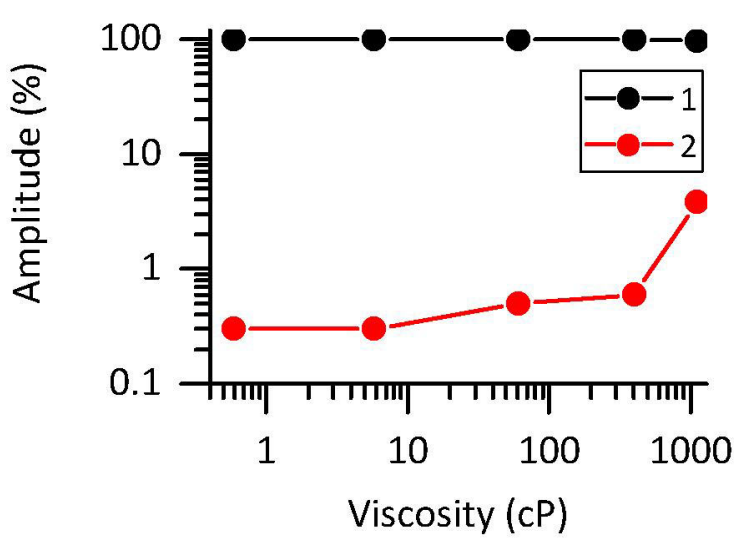

Fig. 2. The fluorescence decay curves of $3 \mathrm{Pi}(\mathrm{a})$ and $3 \mathrm{Pyr}(\mathrm{b})$ in solvent mixtures of different viscosities. (c, d) and $(e, f)$ show the fluorescence lifetimes and amplitudes, respectively. The 3Pi decay curves were fitted using a triexponential model, while a biexponential model was sufficient for the $3 \mathrm{Pyr}$ decays. The excitation wavelength was $375 \mathrm{~nm}$, the fluorescence was detected at $520 \mathrm{~nm}$. 
and 3Pyr demonstrated dependence on viscosity (Fig. 2(c), black), which increased from 50 ps up to 450 ps with increasing the viscosity. In contrast, the remaining two components did not show any significant dependence on viscosity. As a result, we assigned the dominant component to the fluorescence from the initial state populated immediately after excitation. The increase of the lifetime of this component with viscosity supports the hypothesis that the molecule leaves the fluorescent state through the intramolecular rotation, which is expected to be slower at higher viscosities. The origin of other components whose lifetimes and amplitudes are shown in red and green in Fig. 2(c, e) (3Pi) and in red in Fig. 2( d, f) (3Pyr) remained unclear. One possibility could be fluorescence from the TICT states at which the dyes go upon leaving the fluorescent state. Another reason could be that a small amount of aggregates of the dyes have significantly longer lifetimes.

In order to investigate this further, we have performed femtosecond transient absorption experiments on $3 \mathrm{Pi}$ and 3Pyr. We expected the transient absorption data to reveal the following: a) what ultrafast processes that could not be seen in the time-resolved fluorescence data occur after exciting $3 \mathrm{Pi}$ and $3 \mathrm{Pyr} ; \mathrm{b}$ ) whether $3 \mathrm{Pi}$ and $3 \mathrm{Pyr}$ enter any transient states upon leaving the initial fluorescent state and if we could see any signatures of these transient states; c) how quickly both fluorophores return to the ground state upon excitation. The transient absorption data of $3 \mathrm{Pi}$ and 3 Pyr measured at low $(0.59 \mathrm{cP})$ and high $(403 \mathrm{cP})$ viscosities is shown in Fig. 3. Black curves denote the global fits of the transient absorption data. At longer delay times at low viscosity, the transient absorption spectra of both dyes go back to zero, which means that no long-lived states form upon excitation. Additionally, 3Pi was expected to show a negative ground state bleach (GSB) band at $410 \mathrm{~nm}$ and also a negative stimulated emission band at $520 \mathrm{~nm}$ because they should match the positions of the absorption and the fluorescence spectra (Fig. 1(c)). Instead, we see positive excited state absorption (ESA) bands localized at 450 and $550 \mathrm{~nm}$ and no negative bands (Fig. 3 (a, c)). Most likely, this is a result of a wide positive ESA band spanning the whole spectrum that overlaps with the negative GSB and SE bands. Consequently, a positive signal with gaps at 400 and $520 \mathrm{~nm}$ is observed, where ESA and GSB or SE bands cancel each other out.

Overall, there are no significant changes in the shape of the bands in the spectra of 3Pi with increasing delay times. The spectra become less intense but this is caused by the relaxation of $3 \mathrm{Pi}$ back to the ground state. However, a closer inspection of the spectrum of $3 \mathrm{Pi}$ reveals that there is a slight shift of the $550 \mathrm{~nm}$ band to shorter wavelengths with increasing delay time. This could be caused by a relaxation of the molecule in the excited state due to solvent relaxation or vibrational cooling. Such relaxation would result in a higher energy gap between the first and higher excited states, which results in this ESA band. Due to the higher energy gap, the wavelength of the band would decrease.

As seen in Fig. 3(c), the increase of viscosity also has no impact on the shape of the bands but it does slow down the rate at which the bands decrease in intensity, which again confirms the hypothesis that $3 \mathrm{Pi}$ relaxes through intramolecular rotation. Viscosity makes it slower, which leads to a slower relaxation and a slower decrease of the intensity of the bands in the transient absorption spectra.

The transient absorption spectra of $3 \mathrm{Pyr}$ (Fig. 3(b, d)) show a negative band at $420 \mathrm{~nm}$ and a positive band at $460 \mathrm{~nm}$. The former must be a GSB band because the wavelength coincides with the maximum of the absorption of $3 \mathrm{Pyr}$ (Fig. 1(d)). The $460 \mathrm{~nm}$ band is caused by the excited state absorption, whereas a SE band is not seen at $520 \mathrm{~nm}$ (peak fluorescence wavelength) due to an overlap with the ESA band. Finally, the feature seen at $550-650 \mathrm{~nm}$ is most likely caused by two overlapping ESA bands. Similarly to 3Pi, one ESA band of $3 \mathrm{Pyr}$ (at $470 \mathrm{~nm}$ ) shows a shift to a higher wavelength with increasing the delay time. This is probably caused by a shift of the negative SE band, which then overlaps with the red edge of the ESA band and creates impression of the ESA band shifting to a higher wavelength. The transient absorption spectra of $3 \mathrm{Pyr}$ measured at higher viscosity (Fig. 3(d)) show the same behaviour as 3Pi. The shape of the spectra remains the same, only the decrease in intensity becomes slower due to a slower relaxation at high viscosity. Therefore, 3 Pyr also seems to relax through intramolecular rotation. 
(a)

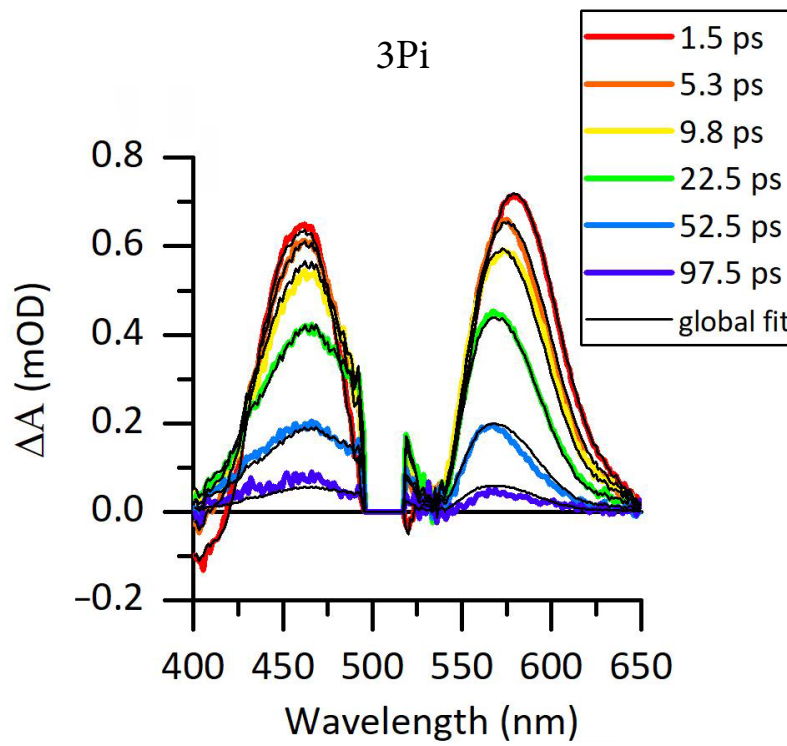

(c)

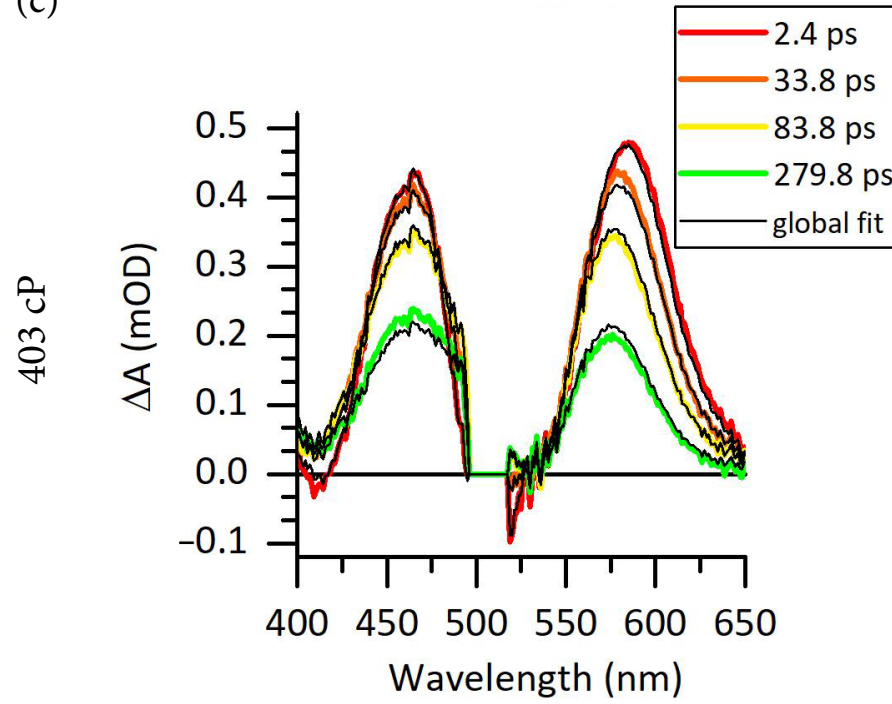

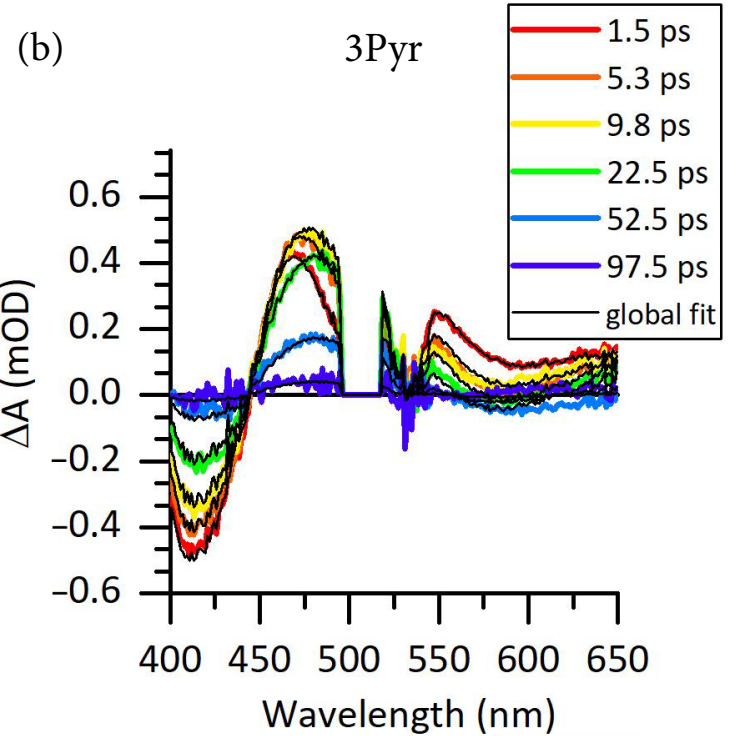

(d)

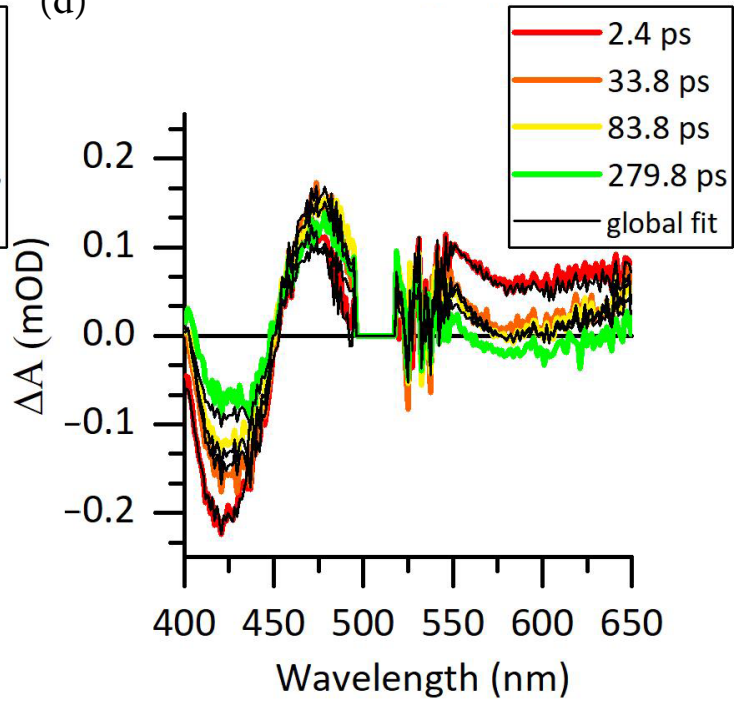

Fig. 3. The transient absorption spectra of 3Pi and 3Pyr in methanol-glycerol mixtures at viscosities of $0.59 \mathrm{cP}$ (a, b) and $403 \mathrm{cP}(\mathrm{c}, \mathrm{d})$. The black lines represent the global fits. The spectral region at 495-515 nm was cut out due to noise caused by a weak intensity of the probe beam at that spectral region. The samples were excited with $390 \mathrm{~nm}$ light.

After measuring the transient absorption spectra, global analysis was performed in order to find signatures of any transient states that are formed after exciting 3Pi and 3Pyr. The spectra were globally fitted using two components. No significant improvement to the fit was observed when the third component was introduced, which means that only two transient species were formed upon excitation. For reconstructing the spectra of the individual species that were formed upon excitation, we have obtained evolution-associated spectra (EAS) assuming a sequential model $\left(\mathrm{GS} \stackrel{h v}{\rightarrow} \mathrm{ES}_{1} \stackrel{k_{1}}{\rightarrow} \mathrm{ES}_{2} \stackrel{k_{2}}{\rightarrow} \mathrm{GS}\right)$.
Here, GS is a ground state, and $\mathrm{ES}_{1,2}$ are two distinct states in the first electronic excited state. The EAS are shown in Fig. 4. The spectra of the $\mathrm{ES}_{1}$ state are shown in black, whereas the ones for the $\mathrm{ES}_{2}$ state are denoted in red. For 3Pi, both spectral components have very similar features (Fig. 4(a)). Such similarity suggests that the two transient species observed are excited fluorophore in the Franck-Condon (FC) state, from where the molecule rapidly relaxes into the locally excited (LE) state. Such transition does not normally lead to significant changes in the transient absorption spectra. The only 
(a)

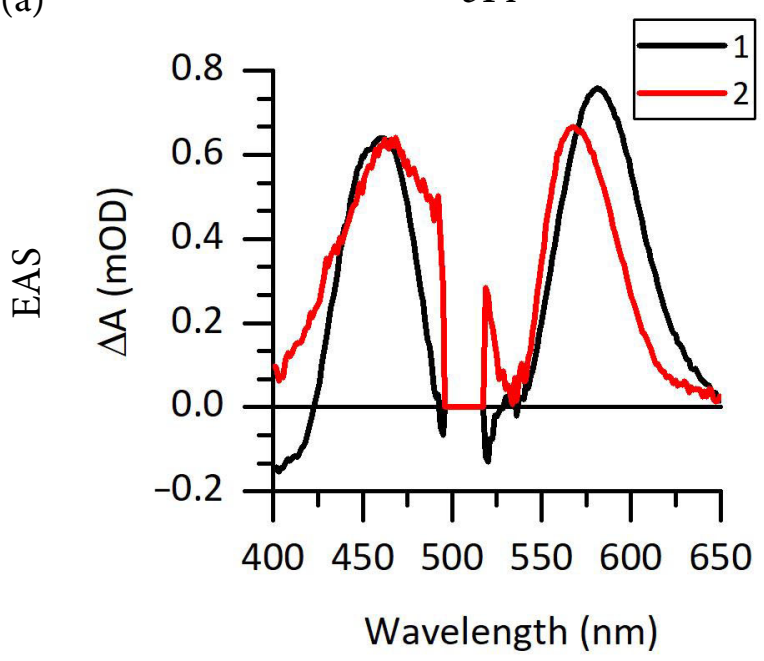

(b)

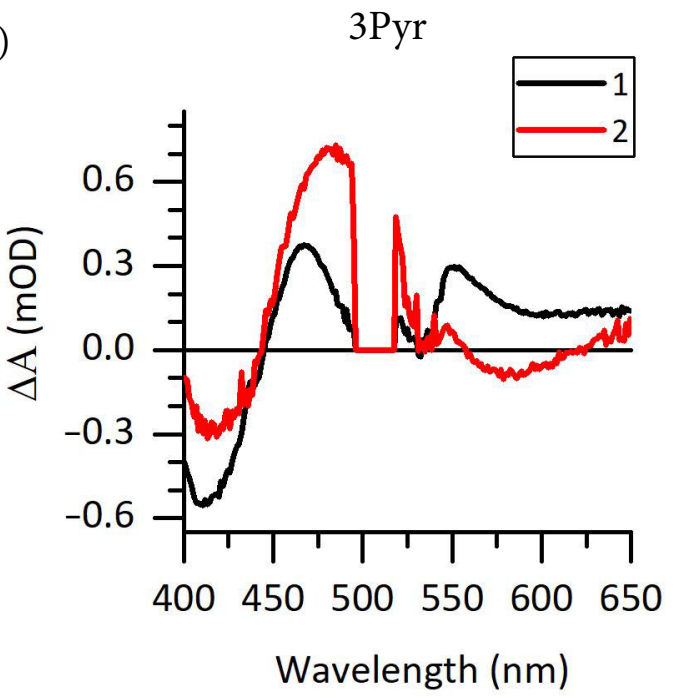

Fig. 4. Global analysis results of the transient absorption data of 3Pi (a) and 3Pyr (b). The evolution associated spectra (EAS) are presented, which were obtained using a sequential fitting model. Two components were used for obtaining a sufficient fit; Component 1 has a lower lifetime than Component 2. Only the results obtained at $0.59 \mathrm{cP}$ viscosities are presented.

difference is a shifted band at $550-600 \mathrm{~nm}$ in the $\mathrm{ES}_{2}$ spectrum relative to the $\mathrm{ES}_{1}$ spectrum, which is likely resulted from solvent relaxation or vibrational cooling as explained previously. Thus we assigned the $\mathrm{ES}_{1}$ and $\mathrm{ES}_{2}$ states to the FC and the LE states, respectively. There are larger differences in the spectral components of 3 Pyr (Fig. 4(b)), but they are also not very significant. First of all, the $\mathrm{ES}_{2}$ spectrum has a two times stronger ESA band at $470 \mathrm{~nm}$, which means that the absorption of the first excited state is stronger after relaxing from the $\mathrm{ES}_{1}$ state. Also the position of the peak is slightly shifted to a higher wavelength. This is a result of a gradual shift of the ESA peak as observed in Fig. 3(b). Due to the small observed differences, we also assigned $\mathrm{ES}_{1}$ and $\mathrm{ES}_{2}$ to the FC and LE states, respectively, as for $3 \mathrm{Pi}$. The fact that we could observe the LE state points that the energy barrier preventing the intramolecular rotation and, as a result, the transition to the TICT state is very likely to be present. Otherwise, the molecule would be unlikely to stay in the LE state at all and it would relax to the TICT state straight from the FC state.

The lifetimes of both components and their dependence on solvent viscosity are shown in Fig. 5. The relaxation from the FC state to the LE state occurs within approximately 10 ps for both fluoro- phores at all viscosities (dash-dotted lines, Fig. 5). Significant variation in lifetimes of the FC component is caused by its low value, which makes it sensitive to the uncertainty of the fit. In contrast to the lifetime of the first component, the second lifetime is viscosity dependent. Also, the values closely match the fluorescence lifetime values of $3 \mathrm{Pi}$ and $3 \mathrm{Pyr}$ obtained from the time-resolved fluorescence measurements (Fig. 2(c, d) and Fig. 5, solid lines). This supports our assignment of the second component in transient absorption data to the fluorescent LE state. The lack of the third component in the transient absorption data means that the TICT state either does not form or it is a very short-lived state, from which the molecule rapidly relaxes to the ground state. This disproves the assumption made in the previous work [11] that the long lifetime component observed in time-resolved fluorescence decays could arise from the TICT state.

Overall, the key observations for the transient absorption data are the following: 1) no long-lived states seem to be formed upon exciting $3 \mathrm{Pi}$ and 3 Pyr; 2) only two transient species are observed upon excitation, which are an excited molecule in the FC state and then a molecule in the LE state that was formed upon relaxation from the FC state; 3 ) the hypothesised TICT state that was supposed to form after relaxation from the LE state 


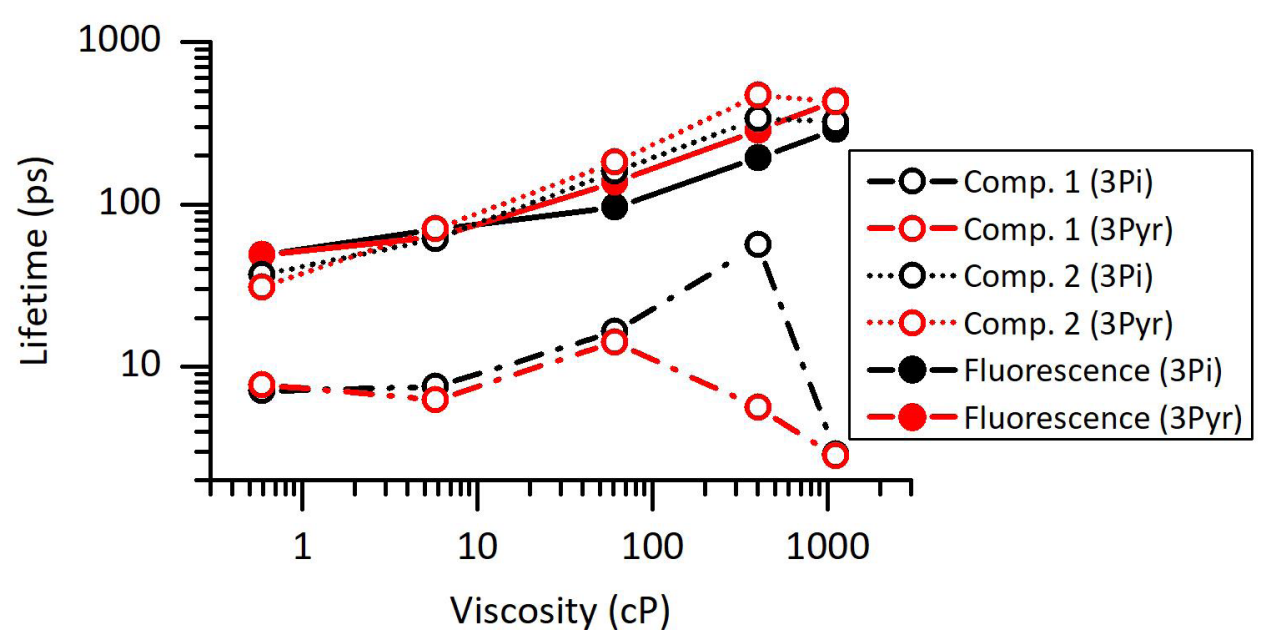

Fig. 5. The lifetimes of both components obtained from the global fits of transient absorption spectra (empty circles) in comparison to the fluorescence lifetimes of the dominant exponential component (filled circles) from the fluorescence decays of 3Pi (black) and 3Pyr (red (online)). Components 1 and 2 are shown in solid and dotted lines, respectively.

shows no signatures in the transient absorption spectra because, according to the data, both fluorophores return to the ground state immediately after leaving the LE state.

\section{Conclusions}

Due to a very poor solubility of fluorescent polyimides (PIs), small molecular weight compounds closely resembling the repeating unit of the PIs were studied in order to gauge the properties of PIs themselves. We have investigated the relaxation mechanism of two model compounds for the fluorescent PIs - 3Pi and 3Pyr. To achieve this, we have performed time-resolved fluorescence and ultrafast transient absorption experiments on both fluorophores in environments of different viscosity. The results demonstrate that a higher viscosity prolongs the time fluorophores stay in the fluorescent state, which means that intramolecular rotation is crucial for non-radiative relaxation of these molecules. This supports our previous hypothesis that these dyes relax via the TICT state. The transient absorption spectroscopy data revealed the formation of two transient species of $3 \mathrm{Pi}$ and $3 \mathrm{Pyr}$ that were assigned to the $\mathrm{FC}$ and $\mathrm{LE}$ states. This indicates that no signature of the TICT state was observed, which means that it must be a very short-lived state out of which both dyes rapidly relax to the ground state. Overall, our re- sults demonstrate that intramolecular rotation has to be suppressed in PIs in order to have a stronger fluorescence. Also, our results both confirmed and expanded upon the previously given mechanism for the relaxation of $3 \mathrm{Pi}$ and $3 \mathrm{Pyr}$. This helps us to understand the photophysical processes in these important molecules on a deeper level, which is necessary for designing new polymers that exhibit intense photoluminescence.

\section{Acknowledgements}

We would like to thank Dr. Aurimas Vyšniauskas for valuable discussions and help with the data analysis and manuscript preparation. We also thank Dr. Kenta Kanosue for his help with the synthesis of model compounds.

\section{References}

[1] U. Mitschke and P. Bäuerle, The electroluminescence of organic materials, J. Mater. Chem. 10(7), 1471-1507 (2000).

[2] T. Kakinuma, H. Kojima, M. Ashizawa, H. Matsumoto, and T. Mori, Correlation of mobility and molecular packing in organic transistors based on cycloalkyl naphthalene diimides, J. Mater. Chem. C 1(34), 5395-5401 (2013).

[3] X. Huang, S. Han, W. Huang, and X. Liu, Enhancing solar cell efficiency: The search for luminescent 
materials as spectral converters, Chem. Soc. Rev. 42(1), 173-201 (2013).

[4] L. Zhu, J. Qin, and C. Yang, Synthesis, photophysical properties, and self-assembly behavior of amphiphilic polyfluorene: Unique dual fluorescence and its application as a fluorescent probe for the mercury ion, J. Phys. Chem. B 114(46), 14884-14889 (2010).

[5] C. Li, M. Numata, M. Takeuchi, and S. Shinkai, A sensitive colorimetric and fluorescent probe based on a polythiophene derivative for the detection of ATP, Angew. Chem. Int. Ed. 44(39), 6371-6374 (2005).

[6] C.E. Sroog, Polyimides, J. Polym. Sci. Macromol. Rev. 11(1), 161-208 (1976).

[7] T. Matsuura, S. Ando, S. Sasaki, and F. Yamamoto, Polyimides derived from 2,2'-bis(trifluoromethyl)-4,4'-diaminobiphenyl. 4. Optical properties of fluorinated polyimides for optoelectronic components, Macromolecules 27(22), 6665-6670 (1994).

[8] G. Arjavalingam, G. Hougham, and J.P. LaFemina, Emission mechanism in polyimide, Polymer 31(5), 840-844 (1990).

[9] R. Karmakar and A. Samanta, Phase-transfer catalyst-induced changes in the absorption and fluorescence behavior of some electron donoracceptor molecules, J. Am. Chem. Soc. 123(16), 3809-3817 (2001).
[10]T. Soujanya, R.W. Fessenden, and A. Samanta, Role of nonfluorescent twisted intramolecular charge transfer state on the photophysical behavior of aminophthalimide dyes, J. Phys. Chem. 100(9), 3507-3512 (1996).

[11]R. Orita, M. Franckevičius, A. Vyšniauskas, V. Gulbinas, H. Sugiyama, H. Uekusa, K. Kanosue, R. Ishige, and S. Ando, Enhanced fluorescence of phthalimide compounds induced by the incorporation of electron-donating alicyclic amino groups, Phys. Chem. Chem. Phys. 20(23), 1603316044 (2018).

[12]M.A. Haidekker, M. Nipper, A. Mustafic, D. Lichlyter, M. Dakanali, and E.A. Theodorakis, Advanced Fluorescence Reporters in Chemistry and Biology III, Springer Series on Fluorescence (Springer Berlin Heidelberg, 2011).

[13]M.A. Haidekker, T. Ling, M. Anglo, H.Y. Stevens, J.A. Frangos, and E.A. Theodorakis, New fluorescent probes for the measurement of cell membrane viscosity, Chem. Biol. 8(2), 123-131 (2001).

[14]A. Vyšniauskas and M.K. Kuimova, A twisted tale: measuring viscosity and temperature of microenvironments using molecular rotors, Int. Rev. Phys. Chem. 37(2), 259-285 (2018).

[15]J.J. Snellenburg, S.P. Laptenok, R. Seger, K.M. Mullen, and I.H.M. van Stokkum, Glotaran: A Java-based graphical user interface for the $\mathrm{R}$ package TIMP, J. Stat. Softw. 49(3), 1-2 (2012).

\title{
RELAKSACIJOS MECHANIZMAS SUŽADINTUOSE FTALIMIDUOSE
}

\author{
I. Čiplys ${ }^{\text {a }}$, R. Orita ${ }^{\text {b }}$, S. Ando ${ }^{\text {, }}$ V. Gulbinas ${ }^{\text {a }}$ \\ ${ }^{a}$ Fiziniu ir technologijos moksly centras, Vilnius, Lietuva \\ ${ }^{\mathrm{b}}$ Tokijo technologijos institutas, Tokijas, Japonija
}

\section{Santrauka}

Fluorescuojantys polimerai yra vieni labiausiai pageidaujamų junginių naujos kartos lanksčių elektronikos komponentų arba spektrinių konverterių gamybai. Dèl savo palankių savybiụ gamybai galètų būti naudojami poliamidai, tačiau jie fluorescuoja labai silpnai. Todèl buvo atlikta nemažai tyrimų siekiant išsiaiškinti silpnos poliamidų fluorescencijos priežastis ir sukurti geresnius poliamidų variantus. Ftalimidai su amino grupèmis paprastai naudojami kaip modeliniai junginiai fluorescuojantiems poliamidams. Šiame darbe tirtas fotofizikinis dviejų tokių ftalimidų (3Pi ir 3Pyr) relaksacijos mecha- nizmas. Ankstesniame darbe buvo nustatyta, kad šiu junginių fluorescencijos kvantinè išeiga yra gana maža, todèl siekta išsiaiškinti priežastis ir pasiūlyti, kaip būtų galima sustiprinti šių junginių fluorescenciją. Abu junginiai buvo tiriami skirtingos klampos aplinkose pasitelkiant fluorescencinę spektroskopiją su laikine skyra ir ultrasparčiosios trumpalaikès („transient") sugerties spektroskopiją. Rezultatai parodé, kad vidumolekulinè rotacija yra būtinas procesas nespindulinei molekuliu relaksacijai, kuri turi būti sustabdyta norint sukurti stipriai fluorescuojančias medžiagas. 